\title{
The Influence Of Giving Communication, Information And Education (KIE/IEC) Toward Pregnant Woman Behavior In Implementing Genital Hygiene
}

\author{
Reny Nugraheni*, Wahyu Sri Astutik \\ IIK Bhakti Wiyata Kediri, East Java, Indonesia \\ reny.nugraheni@iik.ac.id
}

\begin{abstract}
Infection in the vagina is an important health problem for women because it has a negative impact on health and family life and has a tendency of increasing prevalence worldwide. To improve health behavior in pregnant women regarding the cleanliness of the genital area, one approach can be through Consultation, Information and Education at the time of the ANC. To indicate the effect of the provision of IEC on the behavior of pregnant women in carrying out genital hygiene in the work area of the Gurah Health Center in Kediri Regency 2019. This study uses a quassy experiment method, a research carried out by analyzing the effect of an action without considering other influential factors

Before implementing IEC, it was known that most respondents had sufficient behavior in the category of 21 respondents (56.76\%) and as many as 16 respondents (43.24\%) had behaviors in the less category. After implementing IEC, it is known that there was a tendency for the increase in respondent behavior, namely 33 respondents $(89.19 \%)$ in the good category and 16 respondents $(43.24 \%)$ of respondents had good behavior.

There is an effect of giving IEC to the behavior of pregnant women in implementing genital hygiene in the Work Area of the Gurah Health Center of Kediri Regency in 2020. The need for intensive IEC giving measures to pregnant women to improve the behavior of pregnant women in the implementation of genital hygiene so as to prevent pregnant women from various problems of the impact of genital hygiene that are not implemented properly.
\end{abstract}

Keyword : Information and Education Communication, Pregnant Women, Genital Hygiene 


\section{STRADA Jurnal Ilmiah Kesehatan}

DOI: $10.30994 /$ sjik.v9i1.237

ISSN: 2252-3847 (print); 2614-350X (online)

Vol.9 No.1. May 2020. Page.198-205

\section{INTRODUCTION}

Genital hygiene practices are genital care measures that must be kept clean to prevent the growth of fungi or bacteria (Marwati, 2014). One result of the lack of genital hygiene practices is the occurrence of reproductive health disorders such as vaginal discharge, reproductive organ infections, the possibility of cervical cancer risk (Badaryati, 2012).

Infection in the vagina is an important health problem in women because it has a negative impact on health and family life and has a tendency of increasing prevalence throughout the world. Vaginal infection is the most common cause that is the reason for women to seek medical help, especially obstetrics and gynecology clinics (Workowski, 2010).

Every year, around 100 million women in some places in the world are exposed to genital area infections including urinary tract infections and bacterial vaginosis, and $75 \%$ of women have had genital area infections in their lives (Emel, 2011).

Previous studies mention the incidence of bacterial vaginosis in pregnant women varies in several countries, in Africa is estimated to reach 29.1\%, (Kirakoya et al, 2008) in the West African ANC clinic by $29 \%$ - 49\%, in Burkina Faso by $13 \%$ and in Kenya, southern Africa at 21-29\% (Sunay, 2011). According to data from WHO the incidence of bacterial vaginosis in pregnant women ranges from 14-21\% in European Countries (Ocviyanti, 2010) in Asia to $13.6 \%$ in Japan, 15.9\% in Thailand and 32\% in Indonesia (Bahra, 2009 and Joesoef et all, 2001). Research by Madhivanan in India in 2 hospitals found bacterial vaginosis of $15.4 \%$ of pregnant women (Mandhivanan, 2008).

According to WHO (World Health Organization) in 2010 MMR in Indonesia reached 228 / 100,000 live births. One cause of maternal death is infection in pregnancy which reaches $50 \%$. Infectious diseases that occur in pregnant women can also increase the risk of preterm labor, low birth weight (LBW), and the occurrence of premature rupture of membranes (KPD) (Kemenkes, 2012).

In pregnant women, the $75 \%$ incidence of vaginal infections is caused by the use of vaginal douches and poor hygiene of the genitalia (vulva hygiene) (Mahmood, 2011). Infection due to poor cleaning of the genital area can cause 10-20\% of preterm labor, $50 \%$ of cases of preterm labor and premature rupture of membranes (KPD), and $36 \%$ of neonatal deaths (Kemenkes, 2012).

Hygiene in pregnant women is needed so that the baby they are born with is healthy and the mother's health is maintained. Cleanliness of the genital area is the maintenance of hygiene and genital health in order to avoid reproductive disorders (Suryati, 2012). Factors that can increase the risk of infection in the genital area are bad hand washing habits, how to clean genitalia area that is not right after using the toilet, and the use of underwear that is not appropriate (Ott, et al., 2009).

Factors that can increase the risk of infection in the genital area are bad hand washing habits, how to clean genitalia area that is not right after using the toilet, and the use of underwear that is not appropriate (Ott, 2009).

To improve health behavior in pregnant women regarding the cleanliness of the genital area, one approach can be through Consultation, Information and Education at the time of the ANC. According to research conducted by Cankaya and Yilmaz (2015), lack of knowledge and behavior about genital area hygiene in women before pregnancy will not change when the woman is pregnant. This is evidenced by $70 \%$ of pregnant women still having the wrong behavior in doing vulva hygiene during pregnancy. Health service providers for pregnant women must increase awareness of pregnant women to adopt preventive behavior against infections during pregnancy (Nwambo, et al., 2016). 


\section{STRADA Jurnal Ilmiah Kesehatan}

DOI: $10.30994 /$ sjik.v9i1.237

\section{METHODS}

\section{Research design}

This study uses a quassy experiment method, a research carried out by analyzing the effect of an action without considering other influential factors (Notoatmodjo, 2013).

\section{Place and time of research}

This research was carried out in the Work Area of the Gurah Health Center in Kediri Regency in May - December 2019, which included 9 Independent Practice Midwives, 1 Supporting Health Center and 1 Main Health Center.

\section{Population and Sample}

The population studied was all pregnant women who carried out ANCs in the Work Area of the Gurah Health Center in Kediri Regency as many as 78 people, using accidental sampling techniques, obtained samples of pregnant women who carried out ANC in 9 Independent Practice Midwives, 1 Supporting Puskesmas and 1 Main Puskesmas in the Work Area Gurah Health Center in Kediri Regency in the period of May - December 2019 was 37 people.

\section{Data collection technique}

Data collection is carried out with the following steps:

1. Request the approval of prospective respondents.

2. Conduct structured interviews related to genital hygiene activities for pregnant women 24 hours before ANC.

3. Carry out IEC activities with media brochures and frequently asked questions.

4. After 2 days of home visits to get data on changes in genital hygiene in pregnant women 24 hours after IEC administration.

\section{Data analysis}

Data analysis is carried out in the following stages:

1. Conduct descriptive analysis of respondents' general data, and specific data from interviews before and after the provision of IEC.

2. Specific data are analyzed to obtain criteria with the following references:

Good $67-100 \%$

Enough $34-66 \%$

Less $0-33 \%$

3. Carry out the analysis using a different test on the same sample on an ordinal scale (non-parametric) using the Wilcoxon Mach Pair Test.

\section{RESULTS}

Respondents studied were obtained from 14 independent practice midwives, from 6 subhealth centers and 17 from the main health center. Characteristics of respondents tend to be homogeneous with the level of education most of the respondents are high school or equivalent which is 21 people $(57 \%)$.

Based on the work of respondents, it is known that the majority of respondents do not work or have the status of housewives, namely 24 respondents $(65 \%)$.

The results showed that the condition of respondents' characteristics formed bad behavior, it can be seen from the results of the study which showed that before IEC, it was known 


\section{STRADA Jurnal Ilmiah Kesehatan}

DOI: $10.30994 /$ sjik.v9i1.237

ISSN: 2252-3847 (print); 2614-350X (online)

Vol.9 No.1. May 2020. Page.198-205

that most respondents had sufficient behavior in the category of 21 respondents $(56.76 \%)$ and as many as 16 respondents $(43,24 \%)$ have less behavior

Table 1. Respondents' Behavior in Implementing Genital Hygiene Before Giving IEC/KIE

\begin{tabular}{|c|c|c|c|}
\hline No & Category & Frequency & Prosentase \\
\hline 1 & Less & 16 & 43,24 \\
\hline 2 & Enough & 21 & 56,76 \\
\hline 3 & Good & 0 & 0,00 \\
\hline
\end{tabular}

After giving IEC when respondents conducted ANC at the Independent Practice Midwife, Supporting Puskesmas and Parent Puskesmas carried out an evaluation process by conducting structured interviews, on the behavior of respondents in carrying out genital hygiene it was found that there was a tendency for respondents to increase in behavior by 33 respondents $(89.19 \%)$ in good category and 16 respondents $(43.24 \%)$ of respondents have good behavior.

The analysis shows that the P-value of the research results of 0.02 or $2 \%$ is less than the significant level that is set at 5\%, which means that there is an effect of giving IEC to the behavior of pregnant women in carrying out genital hygiene in the Work Area of Gurah Health Center in Kediri Regency 2020.

\section{DISCUSSION}

Personal hygiene behavior is an understanding, attitude and practice carried out by a person to improve health status, maintain personal hygiene, increase self-confidence, create beauty, and prevent disease (Mardani \& Priyoto, 2010: 10). Personal hygiene is the maintenance of personal hygiene and health carried out in everyday life so as to avoid reproductive disorders and obtain physical and psychological well-being and improve health status (Tapparan \& Pandelaki, 2013). Due to lack of personal hygiene practices is the occurrence of reproductive health disorders such as vaginal discharge, urinary tract infections (UTI), pelvic inflammatory disease (PRP) and the possibility of cervical cancer (Wakhidah \& Wijayanti, 2014).

Before doing IEC, it was known that most respondents had sufficient behavior in the category of 21 respondents $(56.76 \%)$ and as many as 16 respondents $(43.24 \%)$ had behaviors in the less category. This condition occurs due to the fact that most respondents have never gotten information about Genital Hygiene. A person's behavior is formed by the knowledge that that person has. Knowledge is the result of knowing through sensing through the five human senses, namely: the sense of sight, hearing, smell, taste, and touch. Most of human knowledge is obtained through the eyes and ears from written information sources and sound information (Efendi, et al., 2009).

Care of the genetal area is very rarely discussed by the people of Indonesia because it seems taboo and dirty. The vagina is a female reproductive organ that is very susceptible to infection. This is due to the boundary between the urethra and the anus is very close, so that germs such as fungi, bacteria, parasites, and viruses can easily enter the vagina. For this reason, women must be diligent in caring for the cleanliness of their personal areas. Genetal hygiene is a maintenance of genital hygiene especially in women to keep the balance of normal flora in the vagina. Hygiene genitalia is an action taken to prevent infection and 


\section{STRADA Jurnal Ilmiah Kesehatan}

DOI: $10.30994 /$ sjik.v9i1.237

improve cleanliness, especially in the genital organs (Murtiastutik, 2008). According to Notoatmodjo (2011), there are several factors that can affect a person's knowledge and behavior, including: age, experience, work, sources of information, culture, the environment, and education level.

Manurung (2006) revealed that to improve knowledge and behavior can be done by providing information through health education. Health workers have an important role in providing counseling related to pregnancy so that it can increase the knowledge of pregnant women and influence the behavior of pregnant women better in maintaining the health of the mother and fetus.

The results showed that the level of education of respondents in the middle category, namely high school. Education of a mother with a special understanding of reproductive health plays an important role in genital hygiene 1. A mother who has a high education will have better knowledge and by having good knowledge then at the time of providing education about the care of reproductive organs can do well.

Pregnant women feel comfortable talking about hygiene practices with people their own age, with knowledge that they think is the same or equal so that the behavior of the nyang formed tends to be homogeneous, in the category of sufficient or less.

After giving IEC, it is known that most of the respondents have good behavior. Factors that can increase the increase in behavior include: age, level of education, and experience (Notoatmodjo, 2011). According to research conducted by Kamath, et al. (2014) is very important for pregnant women in all trimesters to get counseling programs to prevent vaginal candidiasis. The results of his study showed that there was no relationship between hygiene knowledge and behavior with gestational age in all trimesters. Information provided through health education can increase the awareness of pregnant women, especially pregnant women in the last trimester approaching childbirth to improve genital hygiene behavior in preventing pregnancy complications.

According to Hasan and Hasan (2015), the level of education can affect a person's ability to receive information. The information obtained will improve awareness of pregnant women to increase hygiene knowledge and behavior for the sake of their health and the fetus they contain.

One of the reproductive health problems that is often complained of by respondents is vaginal discharge. The main causes of pathological vaginal discharge are infections (fungi, germs, parasites, and viruses). In addition to the main causes, pathological vaginal discharge can also be caused by lack of care for genitalia such as washing the vagina with stagnant water in December, using excessive rinse, using pants that do not absorb sweat, rarely changing panties, not changing pads frequently. Many women in Indonesia who do not know about vaginal discharge so they consider vaginal discharge as a common and trivial matter, in addition to the embarrassment when experiencing vaginal discharge often makes pregnant women reluctant to consult a doctor. very fatal if handled slowly can not only result in miscarriage, vaginal discharge can also be an early symptom of neck cancer which can lead to death.

The problem of cleanliness of sex organs due to lack of knowledge and skills of adolescents, lack of caring parents, and not yet optimal quality of sex organs services. Someone who does not have an understanding of the health of sex organs will tend to ignore the health of sex 


\section{STRADA Jurnal Ilmiah Kesehatan}

DOI: $10.30994 /$ sjik.v9i1.237

organs and in the end will have actions that endanger themselves. Various studies have shown that pregnant women are often wrong in cleaning genitalia, for example, often wrong in washing genital organs from back to front, cleaning genitalia using special soap intimate organs or cleaning fluid with clear composition of the bladder, or sowing powder, even spraying perfume inside. This shows that good and positive information is needed.

There is a significant / significant influence on the use of IEC in the intervention group on genital hygiene behavior which is getting better after being given health education. The provision of IEC which is carried out in a relaxed and family-friendly atmosphere influences pregnant women to be more open in communicating and consulting. IEC which is carried out openly can attract the attention of respondents and increase the motivation of respondents in accepting the material provided so that the material will be easily remembered and applied.

The success of counseling activities is influenced by several factors including the media used and health workers who conduct counseling (Notoatmodjo, 2012). In the interventions carried out, IEC uses leaflet media, making it easier for respondents to understand the stages that must be carried out to carry out genital hygiene. Leaflets are visual based media that rely on the sense of sight (Fathurrohman, 2007). The advantages of using this leaflet media are that it is easy to use and can be read many times. Reading leaflets many times can further increase the understanding of pregnant women related to genital hygiene so that it will affect the genital hygiene behavior of pregnant women better.

A change in good respondent's behavior towards genital hygiene behavior after being given health IEC indicates that the respondent has a good awareness to avoid the negative effects of poor genital hygiene behavior. Observations at the time of IEC implementation by health workers revealed that officers delivered the material well, were able to increase respondents 'participation, and use language that was easy to understand so as to increase respondents' understanding.

The way health workers act as educators in providing health education also determines success in the implementation of health education. The responsibility of an educator is to create a pleasant learning atmosphere and understand the media used in learning. Educators must be able to deliver material with more standards, interesting and interactive learning, and use language that is simple and easy to understand. Provision of information from health workers is very influential on improving genital hygiene behavior scores in pregnant women. This is consistent with what was conveyed by Notoatmodjo (2007) that information obtained accurately from people who are considered important in the health field can influence the positive behavior that will be formed

\section{CONCLUSION}

Before implementing IEC, it is known that the majority of respondents had sufficient behavior in the category of 21 respondents (56.76\%) and as many as 16 respondents (43.24\%) had behaviors in the less category.

After implementing IEC, it is known that there was a tendency for the increase in respondent behavior, namely 33 respondents $(89.19 \%)$ in the good category and 16 respondents (43.24\%) of respondents had good behavior. 


\section{STRADA Jurnal Ilmiah Kesehatan}

DOI: $10.30994 /$ sjik.v9i1.237

ISSN: 2252-3847 (print); 2614-350X (online)

Vol.9 No.1. May 2020. Page.198-205

The results of the analysis show that the P-value of the research results of 0.02 or $2 \%$ is less than the significant level that is set at $5 \%$, which means that there is an effect of giving IEC to the behavior of pregnant women in carrying out genital hygiene in the working area of the Gurah Health Center in Kediri Regency 2020.

\section{REFERENCES}

Anggarawati, D. 2003.Studi Prevalensi dan Keberhasilan Terapi Vaginosis Bakterialis pada Ibu Hamil. (tesis).PPDS Obstetri Ginekologi. Fakultas Kedokteran. Universitas Diponegoro Semarang.

Anggraini, D., Maryuni, S.W., Pratiwi, E.Z., 2012. Prevalensi dan Karakteristik Wanita Hamil Penderita Bacterial Vaginosis di Poliklinik Obstetri dan Ginekologi RSUD Arifin Achmad Pekanbaru. (tesis). Fakultas Kedokteran Universitas Riau.

Bahra, A., Hamid, B., Zohre, T. 2009. Prevalence of Bacterial Vaginosis and Impact of Genital Hygiene Practice in Non Pregnant Women in Zanjan, Iran. Omen Medical Journal 2009. Volume 24.Issue 4.Oktober.

Cankaya S. \& Yilmas D. S. (2015). Factors Associated with Genital Hygiene Behaviours in Pregnant and Nonpregnant Women in Turkey. International Journal of Human Sciences, 12(1), 920-932. doi: 10.14687/ijhs.v12i1.3126.

Dipali N., Seema A., Rupali G. (2009). Impact of Health Education on Knowledge andPractices About Menstruation Among AdolescentSchool Girls of Kalamboli, NaviMumbai.Health and Population: Perspectives and Issues Vol. 32 (4), 167- 175.

Efendi, Ferry, Makhfudli. (2009). Keperawatan Kesehatan Komunitas: Teori dan Praktik dalam Keperawatan. Jakarta: Salemba Medika.

Emel, O., Nazan, O., Asya, B. et al. 2011.Some Hygiene Behaviour and Genital Infection Complaints Among 15 - 49 Aged Women in A Suburban Area Of Istanbul. Nobel Med.7(2): 96-100.

Haryoko, S. (2009). Efektivitas Pemanfaatan Media Audio-Visual Sebagai Alternatif Optimalisasi Model Pembelajaran. Jurnal Edukasi@Elektro Vol. 5, No. 1, Maret 2009, hlm. $1-10$

Holmes, K.K., Mardh, P.A., Sparling, P.F., Lemon, S.M., Stamm, W.E., Piot P, et al. 2005.Bacterial Vaginosis. Sexually Transmitted Diseases.3rd ed. New York: McGraw Hill.563-86.

Margareth, Z. H. (2013). Kehamilan, Persalinan, dan Nifas. Yogyakarta: Nuha Medika.

Notoatmodjo, S. (2011). Promosi Kesehatan \& Ilmu Perilaku. Jakarta: Rineka Cipta. . (2012). Promosi kesehatan dan Perilaku Kesehatan. Jakarta : Rineka Cipta. 


\section{STRADA Jurnal Ilmiah Kesehatan}

DOI: $\underline{10.30994 / \text { sjik.v9i1.237 }}$

ISSN: 2252-3847 (print); 2614-350X (online)

Vol.9 No.1. May 2020. Page.198-205

Nwambo, Joshua C., Nwankwo, Clementina U., Ilo, Clementine I., Ezenduka, Pauline O., Makachi, Monica C. (2016). Preventive Health Behaviours for Infection Among Pregnant Mothers Attending Antenatal Clinics in Nnamdi Azikiwe University Teaching Hospital, Nnewi, Anambra State, Nigeria. Journal of Research in Nursing and Midwifery (JRNM) (ISSN: 2315-568) Vol. 5(2) pp. 045-054, February, 2016.

Ott, M. A., Ofner, S., Fortenberry, J. D. (2009). Beyond douching: use of feminine hygiene products and STI risk among young women. J Sex Med, 6, 5, 1335- 1340. [PMID:19170863].

Putri, S. N. (2012). Hubungan Akses Informasi Kesehatan dengan Health Literacy Mahasiswa Universitas Dian Nuswantoro Semarang. Semarang: Universitas Dian Nuswantoro Semarang.

Suryati. B. (2012). Perilaku Kebersihan Remaja Saat Mentruasi. Jurnal Health Quality. 2012; 3(1): 54-65.

Usman, B. P. R. (2013). Hubungan Perilaku Hygiene Organ Genitalia Eksterna dengan Jenis Keputihan Pada Ibu Hamil Usia Gestasi 11-24 Minggu (Studi kasus Dilakukan di Rumah Sakit Medirossa Cikarang Periode April-Juni 2013). Jakarta: Universitas Islam Negeri Syarif Hidayatullah 